\title{
O problemie polisemii i homonimii w przekładoznawstwie
}

Maciej Kalisz | Uczelnia Lingwistyczno-Techniczna w Świeciu

\section{Streszczenie}

Słowa kluczowe:

polisemia, homonimia, translatologia przekładoznawstwo

Ten artykuł skupia się na zjawisku tłumaczenia ze specjalnym uwzględnieniem problemu polisemii i homonimii. Po pierwsze, przedstawia najistotniejsze problemy występujące w przekładoznawstwie. Po drugie, opisuje główne teoretyczne rozważania na temat polisemii i homonimii, z uwzględnieniem ich roli w tłumaczeniach. Po trzecie, rozważa użycie najbardziej adekwatnych strategii i technik w tłumaczeniu wieloznaczności.

\section{On polysemy and homonymy in translatology}

\section{Abstract}

This paper deals with the phenomenon of translation with special emphasis on polysemy and homonymy. First, it describes the most challenging and the most common obstacles that may occur in the process of translation. Second, it presents the main theoretical approaches to polysemy and homonymy with respect to translation. Third, it presents the possible solutions and linguistic tools which may be useful in dealing with translation problems concerning polysemy and homonymy. 


\section{Główne problemy przekładoznawstwa}

W świecie przekładoznawstwa istnieje powszechna zgoda co do tego, iż największe trudności $w$ translacji sprawiają różnice kulturowe, choć mamy do czynienia $z$ definiowaniem tego zjawiska $w$ różnorodny sposób, na przykład pojawia się propozycja, by wprowadzić między innymi rozróżnienie na nieprzekładalność językową i nieprzekładalność kulturową (Catford 1965). Wydaje się jednak, iż zagadnienie to jako pierwszy dostrzegł i opisał Olgierd Wojtasiewicz w klasycznej już dziś książce Wstęp do teorii tłumaczeń z 1957 roku. Publikacja ta - niestety - nie spotkała się z odzewem zagranicznych lingwistów, zapewne z powodu braku jej tłumaczenia na inne języki. Może też dlatego, że - jak wynika z relacji ustnych - sam autor nie był z owej książki nader dumny. Niemniej jednak kwestia zasygnalizowana w późniejszym czasie była już szeroko opisywana (Nida 1964; Venuti 1995; Hejwowski 2006; 2015 i inni). Odmienności kulturowe mogą mieć oczywiście wiele aspektów, począwszy od geograficznych, polityczno-gospodarczych, po religijne itp.

Różnice geograficznie głównie sprowadzają się do odległości pomiędzy krajem, kręgiem kulturowym języka źródłowego i języka docelowego. Funkcjonuje znana zasada: im większa odległość, tym mniejsza liczba kontaktów, choć w dobie globalizacji zaczyna ona mieć coraz mniejsze znaczenie. Różnice polityczno-gospodarcze nastręczały i nastręczają nie lada problemów w kontaktach i rozumieniu poszczególnych kultur, a także ograniczają lub wręcz zakłócają ich dialog. Przykładem może tu być styczność pomiędzy krajami komunistycznymi a liberalnymi demokracjami w Europie w drugiej połowie ubiegłego wieku. Tak zwany język komunizmu był pełen różnorodnych neologizmów, przekłamań, przeinaczeń, zmian znaczeniowych i niedopowiedzeń. Jednostki leksykalne, takie jak socjalizm, komunizm, demokracja, praca, milicja itp., miały często inny zakres semantyczny w krajach komunistycznych, niż było to ogólnie przyjęte, co w procesie translacji stwarzało znaczne przeszkody, a nawet wywoływało semantyczne i pragmatyczne nieporozumienia. Leksem komunizm w oficjalnej propagandzie Polskiej Republiki Ludowej nie występował właściwie nigdy. Używano go jedynie w kręgach opozycji demokratycznej lub w dyskursie osób nieprzychylnych ustrojowi. Oficjalnie wyraz komunizm zastępowano jednostką socjalizm, co w tłumaczeniu chociażby na język angielski stanowiło pewien problem, gdyż brytyjski socjalizm jest zupełnie odmiennym systemem wartości i idei niż komunizm (Kalisz 2016: 73). Przykłady można by było mnożyć.

Różnice religijne w rozumieniu i - co za tym idzie - w przekładzie nie dotyczą zazwyczaj głównych dogmatów i pryncypiów konkretnego wyznania, gdyż są one - lub przynajmniej być powinny - powszechnie uświadamiane. Dotyczą one głównie tradycyjnych uroczystości i obrządków religijnych. Trudno byłoby jednak przedstawić w przekładzie z języka polskiego na mandaryński czy kantoński czerń jako metaforę smutku i żałoby, ponieważ w Chinach kolorem żałoby jest biel. Jak wiadomo, biel w kulturze polskiej ma zupełnie odmienną symbolikę. 
Można oczywiście wymienić wiele innych różnic kulturowych, w tym sporo egzotycznych. Trudno będzie zapewne przedstawić w tłumaczeniu na języki prymitywnych (określenie prymitywny nie zostało tu użyte w znaczeniu pejoratywnym!) plemion indiańskich Ameryki Południowej proste zdanie: Spotkajmy się w sobotę o szesnastej, jako że w tej kulturze, a więc i w języku docelowym, koncepcje dni tygodnia i podziału doby na godziny są zjawiskiem obcym. Interesujące rozważania prezentuje gdańska badaczka Danuta Stanulewicz, która szczegółowo analizuje procesy translacji z języków indiańskich (Stanulewicz 2000: 222-224). Zaznacza przy tym, iż tłumaczenie z nich na języki europejskie przysparza niemałych trudności w związku ze zgoła odmiennym widzeniem przez Indian świata w różnych jego wymiarach. W aspektach kulturowych chodzi przede wszystkim o kwestie podstawowe, takie jak postrzeganie przestrzeni, swoiste rozumienie upływu i roli czasu czy wreszcie roli człowieka jako części otaczającej go rzeczywistości. Te różnice przekładają się na kwestie zasadniczej odmienności języków indiańskich od europejskich, zarówno pod względem opisu semantycznego, jak i specyficznej z punktu widzenia Europejczyka gramatyki (Stanulewicz 2000: 222-224).

Do niezwykle złożonych kwestii przekładowych należą te związane z gramatyką języka. Ze względu na olbrzymią (ok. 7 tys.) liczbę istniejących języków i tyluż systemów gramatycznych trudno nawet zaryzykować propozycję jakiejś syntetycznej, ujednoliconej zasady. Językoznawcy, rzecz oczywista, tworzą najrozmaitsze teorie gramatyk - gramatykę generatywno-transformacyjną (Chomsky 1965), gramatykę kognitywną (Langacker 1987) i inne.

\section{Homonimia i polisemia}

Kolejnym, niezwykle istotnym, dylematem $w$ translatologii jest zjawisko wieloznaczności i wszelkie związane z nim implikacje. Fundamentalnymi elementami niejednoznaczności są kategorie polisemii i homonimii (Wojan 2010). Podstawowy podział na homonimię i polisemię bywa zazwyczaj definiowany za pomocą różnorodnych utrwaleń hasłowych w słownikach. Polisemia występuje jako jedno hasło z kilkoma znaczeniami, natomiast homonimia stanowi samodzielną jednostkę leksykalną o odrębnym znaczeniu (Lyons 1995: 58). Należy jednak zaznaczyć, iż ich faktyczna delimitacja w praktyce przysparza licznych trudności. Decyduje o tym wiele czynników, między innymi kontekst, indywidualna świadomość językowa, różnice między językami, różnorodna interpretacja, konwencjonalizacja, metaforyzacja, zmiana znaczenia czy rozszerzenie znaczenia. Podział słownikowy zjawiska niejednoznaczności leksykalnej bywa jednak często nieprecyzyjny, a nawet zwodniczy (Wojan 2010: 81-84). Tadeusz Danilewicz zauważył, że w niektórych słownikach poszczególne hasła klasyfikowane są jako homonimy, a w innych jako polisemy, np. mouth jako 'część ciała' lub jako 'otwarcie' w Longman Dictionary of English Language and Culture traktowany jest 
jako polisemiczny, natomiast Cambridge International Dictionary of English przedstawia mouth jako dwa odrębne hasła (Danilewicz 2011: 256).

\section{Homonimia}

Jak wspomniano, trudno jest jednoznacznie oddzielić homonimię od kategorii, jaką jest polisemia. Dlatego też nie należy czynić zarzutów merytorycznych leksykografom, mając świadomość nieprecyzyjności kryteriów rozróżniania obu zjawisk. Jurij Apresjan dostrzegał nawet podział na wieloznaczność i homonimię. Wieloznaczność rozumiana jest tutaj jako znacznie szersze zjawisko niż homonimia, która z kolei traktowana jest jako zjawisko skrajne (Apresjan 1980: 235-237). Podobny pogląd, choć z pewnymi zastrzeżeniami, przedstawia Tomasz Gizbert-Studnicki. Chodzi tutaj przede wszystkim o brak ostrego kryterium rozróżnienia leksemów o wielu znaczeniach od par jednostek o tożsamej formie, ale różnych znaczeniach (Gizbert-Studnicki 1978: 46; Wojan 2010: 75-81, 194-218). Elżbieta Awramiuk homonimię definiuje w następujący sposób:

Homonimia - najogólniej mówiąc - polega na wyrażaniu różnych znaczeń za pomocą
identycznej formy językowej. Pojęcia "formy” i „znaczenia” wiążą się z teorią znaku języ-
kowego. Do komunikacji między ludźmi dochodzi za pomocą obiektów fizycznych, mó-
wionych lub pisanych. Obiekty te są jednostkami unilateralnymi i dopiero ich interpretacja
semantyczna (bilateralizacja) pozwala mówić o znaku językowym i stwierdzić, czy mamy
do czynienia z jedną jednostką czy z większą ich ilością. [...] Homonimia oznacza sytuację,
w której dwie językowe jednostki bilateralne mają ten sam wykładnik tekstowy (Awramiuk
2011: 29).

Z kolei Tomasz Krzeszowski ujmuje problem w sposób następujący: należy dokonać dystynkcji pomiędzy homonimią prawdziwą (true homonimy) i homonimią częściową (partial homonymy), gdzie prawdziwa homonimia zawierałaby: 1. niepowiązane znaczenie, 2. identyczność wszystkich form, 3. identyczność form byłaby gramatycznie ekwiwalentna (Krzeszowski 2016: 111). W języku polskim - w przeciwieństwie do angielskiego - taka sytuacja występuje znacznie rzadziej z uwagi na odmienność systemów gramatycznych (np. deklinacje, koniugacje, podmiot domyślny). Na przykład leksem zdjęcie w zdecydowanej większości form występuje w identycznych wersjach, natomiast formy: zdejmować, zdejmowany, zdejmowana, zdjęli itd. odnosić się będą wyłącznie do czasownika, a zatem jednostka ta nie spełnia ani drugiego, ani trzeciego wymogu. Z kolei czasowniki nie odmieniają się przez przypadki. Homonimia częściowa musi zaś spełniać warunek identyczności przynajmniej jednej formy, np. found jako forma czasu przeszłego czasownika to find 'odnajdywać' czy found jako generyczna forma czasownika to found 'zakładać, ustanawiać'.

Tradycyjna klasyfikacja lingwistyczna zjawisk homonimii bazuje na rozróżnieniu: a. homonimii leksykalnej, b. homonimii słowotwórczej, c. homonimii składniowej, 
d. homonimii fleksyjnej, e. homonimii fonetycznej (Buttler 1971a; 1971b; Majewska 2002: Wojan 2010).

\section{Homonimia międzyjęzykowa}

Z punktu widzenia przekładoznawstwa najbardziej interesujące są naturalnie badania w zakresie szeroko pojętej homonimii międzyjęzykowej. Jedną z ciekawszych propozycji przedstawia Katarzyna Wojan, która wprowadza podział na: a. międzyjęzykową homonimię wewnętrzną (wewnątrzjęzykową), b. międzyjęzykową homonimię zewnętrzną (zewnątrzjęzykową) oraz c. międzyjęzykową homonimię semantyczną (Wojan 2001; Wojan 2004; Wojan 2010). Międzyjęzykowa homonimia wewnętrzna zakłada istnienie identycznej lub prawie identycznej formy brzmieniowej lub graficznej leksemów w co najmniej dwóch językach; muszą one wszakże być homonimami również w ramach własnych systemów językowych. Autorka ilustruje podział zjawisk przykładami z języka polskiego, fińskiego i rosyjskiego (Wojan 2010: 270):

w języku polskim:

aura I 1. książk. 'stan pogody'; 2. 'nastrój klimat, atmosfera panujące w jakimś środowisku'; 3. przen. 'stosunki panujące, atmosfera;

aura II 1. med. 'objawy przedchorobowe, stan neuropsychiczny'; 2. spiryt. 'część ciała astralnego';

w języku fińskim:

aura I 1. gwar. 'socha'; 2. rol. 'pług';

aura II 1. geogr. nazwa rzeki (Aurajoki); 2. geogr. nazwa regionu w Finlandii;

aura III 1. obraz. 'pogoda'; 2. przen. 'atmosfera, stosunki panujące w jakimś środowisku'; aura IV 1. med. 'objawy przedchorobowe, stan neuropsychiczny'; 2. 'część ciała astralnego'; w języku rosyjskim:

aypa I psych. 'klimat, stosunki panujące';

aypa II. astrol. 'Aura';

aypa III. 1. med. 'stan neuropsychiczny, zapowiedź histerii'; 2. parapsych. 'część ciała astralnego'.

Można tu uzupełnić jeszcze o wersję w języku angielskim:

aura I psych. 'nastrój, stan psychiczny';

aura II przen. 'atmosfera, stosunki panujące w jakimś środowisku';

aura II tech. 'ruch powietrza w naelektryzowanym punkcie';

aura III med. 'stan neuropsychiczny, zapowiedź epilepsji lub histerii'.

W wypadku międzyjęzykowej homonimii zewnętrznej (termin Wojan) mogą pojawić się problemy translacyjne. Na ogół poprawne tłumaczenie będzie umożliwiał kontekst wypowiedzi, jednak nie zawsze bywa on dostatecznie precyzyjny. Najmniej wątpliwości w przekładzie spowodują znaczenia geograficzne lub techniczne - mało prawdopodobne będzie pomylenie zjawiska wyładowań elektrostatycznych z nazwą rzeki. Najwięcej trudności, jak się wydaje, mogą wygenerować znaczenia psychiczno-medyczne. Stan nastroju psychicznego cechuje się bowiem dużym zróżnicowaniem: 
od egzaltacji - przez przygnębienie i złość - po zachowania histeryczne. Z kolei stan zapowiadający atak epilepsji jest bardzo groźnym stanem chorobowym i nie ma przecież wiele wspólnego $z$ dobrym lub złym humorem. Trudno byłoby zatem zaproponować tu jakąś konkretną strategię translacyjną, jakkolwiek można przedłożyć konkretne rozwiązania oraz narzędzia translatoryczne. Optymalnym rozwiązaniem byłoby zapewne zastosowanie ekwiwalentu. $Z$ teoretycznego punktu widzenia nie jest to już jednak tak oczywiste. Wynika ono bowiem z mnogości rodzajów ekwiwalentów występujących w literaturze. Można byłoby również zaryzykować twierdzenie, że mamy tu do czynienia ze swoistą proliferacją terminologiczną. W przypadkach trudności ekstremalnych tłumacz może zawsze wspomóc się narzędziem w postaci przypisu objaśniającego.

Międzyjęzykowa homonimia zewnętrzna zakłada również istnienie identycznej lub niemal identycznej formy brzmienia lub pisowni leksemów w co najmniej dwóch językach. W tym wypadku dane jednostki leksykalne nie muszą spełniać kryterium homonimiczności we własnych systemach językowych. Dlatego też bardzo często to zjawisko bywa porównywane do fenomenu fałszywych przyjaciół (false friends). W tym wypadku tłumacz powinien być świadomym zagrożenia, jakie może wypływać $z$ automatycznego tłumaczenia takiej jednostki, by nie popełnić zasadniczego błędu translacyjnego. Typowym przykładem takiego błędu (występującego w wielu powieściach, filmach i gazetach) jest tłumaczenie angielskiej jednostki caucasian oznaczającej rasę białą jako rasa kaukaska. W pewnej mierze pomocne w uporządkowaniu tego galimatiasu powinny być słowniki fałszywych przyjaciół. W wersji angielsko-polskiej dostępnych jest co najmniej osiem tytułów (zob. Wojan 2013: 207). W świetle bardziej rygorystycznych reguł porządkujących międzyjęzykowa homonimia wewnętrzna powinna stanowić podzbiór homonimii zewnętrznej. Katarzyna Wojan (2010: 270) na tę okoliczność przedstawia szereg przykładów z języka rosyjskiego i polskiego, między innymi:

ros. Mopc 'napój owocowy'

pol. mors 'gatunek ssaka morskiego'.

Niezależnie od tego, czy będziemy te przykłady traktować jako przejaw międzyjęzykowej homonimii zewnętrznej czy też tak zwanych fałszywych przyjaciół, należałoby założyć, że problemy przekładowe częściej będą pojawiały się w tłumaczeniach ustnych. Wynikają one w dużej mierze z ograniczonego czasu reakcji tłumacza przy płynności aktu samego przekładu. Najlepiej byłoby zaufać doświadczeniu tłumacza i zdać się na jego talent. Problemy translatorskie dotyczą również homofonów i homografów użytych w grze słów. Jeśli w języku docelowym istnieje podobna konstrukcja semantyczna i gramatyczna (co zdarza się niezwykle rzadko), można dokonać tłumaczenia za pomocą odwzorowania takiej konstrukcji. W pozostałych sytuacjach, podobnie jak w wypadku międzyjęzykowej homonimii wewnętrznej, nie obejdziemy się bez przypisu objaśniającego. Dobrym przykładem "nieprzetłumaczalnej” gry 
słów będzie określenie Zwiq̨zek Zdradziecki. W tym wypadku to właśnie forma opisowa będzie konieczna w objaśnieniu znaczenia takiej gry słów w języku wyjściowym.

Międzyjęzykowa homonimia semantyczna - zdaniem Katarzyny Wojan - powinna stanowić pewnego rodzaju suplement do homonimii zewnętrznej, gdyż mamy tutaj do czynienia ze zbieżnością znaczeniową w kilku sensach, jakkolwiek nie istnieją tu wymogi ani brzmieniowe, ani graficzne. Istnieje natomiast podobieństwo znaków występujących w wyrazach. Międzyjęzykowa homonimia semantyczna może być jednak zastanawiająca jako kategoria podziału w świetle podstawowej definicji homonimii. Po pierwsze, brak zbieżności formalnej mimo wspomnianego podobieństwa znaków stoi przecież w opozycji do definicji. Po drugie, ścisłe podobieństwo znaczeniowe wydaje się czymś wręcz „antyhomonimicznym”. Taka kategoria - oczywiście - jest interesująca, ale czy w jej nazwie powinno występować słowo homonimia? Problem ten badaczka rozwiązała nieco później w swojej dysertacji, nadając zjawisku miano synosemii międzyjęzykowej (Wojan 2007).

\section{Homonimia w ujęciu pragmatycznym}

Zjawisko homonimii można również analizować w ujęciu pragmatycznym. Jurij Apresjan, rozważając problem wieloznaczności, postuluje:

[...] w dostatecznie pełnym słowniku hasło słownikowe powinno w zasadzie mieć strefę pragmatyczną lub konotacyjną, w której zapisane byłyby asocjacje semantyczne, jakie wywołuje wyraz o danym znaczeniu (Apresjan 1980: 230).

Niezwykle ciekawą analizę relacji pragmatycznych w homonimii przedstawia Martyna Król, ukazując występowanie owego zjawiska i jego pozycji w ramach działalności językowej (Król 2014: 143). Mamy tutaj do czynienia, zależnie od przyjętego kryterium, z podziałem na trzy kategorie: 1. homonimię socjolektalną, 2. homonimię dyskursywną i 3. homonimię etnojęzykową. Autorka zaznacza również, że ten podział można jeszcze uszczegółowić, biorąc pod uwagę możliwość występowania danej homonimii w więcej niż jednym socjolekcie, dyskursie lub języku etnicznym. Jako czwarta kategoria z punktu widzenia pragmatyki wyróżniona została także homonimia idiostylistyczna. Odnosi się do indywidualnego pojmowania niektórych leksemów przez poszczególnych użytkowników języka (Król 2014: 144).

Takie indywidualistyczne odkodowywanie poszczególnych jednostek leksykalnych może mieć - oczywiście - wpływ na proces translacji. Choć przy założeniu, że tekst tłumaczony zasadza się na ogólnie przyjętym znaczeniu słów, nie stanowi to zasadniczego problemu w translatologii. Jedynym potencjalnym „zagrożeniem" może być sam tłumacz i jego indywidualne rozumienie znaczenia poszczególnych leksemów. 


\section{Polisemia}

Kolejną kategorią wieloznaczności jest polisemia. Elżbieta Tabakowska, zapytana w wywiadzie o tezę zawartą w wykładzie pt. Polisemia - marzenie autora, koszmar tłumacza, odpowiada:

Teza potwierdzona jest moim wieloletnim doświadczeniem. Polisemia opiera się na wieloznaczności - marzenie autora ze względu na możliwość swobodnego wyrażania myśli, a to jednocześnie może być koszmarem tłumacza - ciężką pracą jest przetłumaczenie dzieła tak, by nie straciło ono swojego sensu (Sas, Tabakowska 2014).

Zjawisko polisemii, podobnie jak zjawisko homonimii, nie rozróżnia ostrych granic semantycznych i posiada kilka odmian. Tomasz Gizbert-Studnicki charakter polisemiczny leksemów przedstawia następująco: „[...] za polisemiczny uznaje się wyraz mający dwa lub więcej znaczeń leksykalnych, między którymi istnieje pewien związek" (Gizbert-Studnicki 1978: 46). Jeśli więc polisemia to w słowniku jedno hasło o kilku znaczeniach, należałoby zastanowić się nad ewentualną kolejnością przedstawiania różnych znaczeń w definicjach. Igor Burkhanow rozważa problem taksonomii znaczeń zjawiska polisemii i zastanawia się, jakie elementy powinny decydować o tym zjawisku (Burkhanov 1998: 184-185). Jako główne czynniki badacz wymienia pierwsze historycznie udokumentowane użycie oraz frekwencyjność. Czynnik prymarny jest o tyle problematyczny (choć logiczny), że pierwsze historycznie udokumentowane użycie nie musi być pierwszym użyciem de facto. Nie dotyczy to na przykład neologizmów. Drugi czynnik można rozpatrywać lub weryfikować za pomocą badań korpusowych. Należy również zastanowić się nad tym, w jaki sposób poszczególne rodzaje polisemii mogą przesądzać o taksonomii znaczeń. Krzeszowski rozróżnia trzy rodzaje polisemii: pozorną polisemię (apparent polisemy), quasi-polisemię oraz prawdziwą polisemię (true polisemy) (Krzeszowski 2016: 106-109).

Pozorna polisemia skupia się na narzucającym się znaczeniu. Znaczeniu, które zdecydowanej większości użytkowników języka przyjdzie na myśl niejako „od razu”. Za przykład mogą tu posłużyć jednostki w rodzaju stołu czy krzesła. Natomiast inne warianty zarówno z semantycznego, jak i pragmatycznego punktu widzenia będą realizowane imaginacyjnie w zależności od kontekstu czy specyficznej sytuacji komunikacyjnej. Można zatem ten rodzaj polisemii uznać za najbardziej prawdopodobnego kandydata na pojęcie posiadające najbardziej prototypowe cechy znaczeniowe. Nie sposób nie zauważyć, iż w takim ujęciu znaczenie może być również poparte teorią prototypu językowego rozumianego tu jako modelowy, konkretny element kategorii pojęciowej (zob. Langacker 1987), na przykład angielska jednostka circle i polska koło, bo w zależności od kontekstu, mogą odnosić się do figury geometrycznej lub do stowarzyszenia/organizacji, tj. circle of assassins i koło gospodyń wiejskich. W obu wypadkach figura geometryczna będzie owym znaczeniem „samonarzucającym się". Niekiedy problemy translacyjne mogą skutkować rozszerzeniem znaczenia wyrazów 
w języku docelowym. Proces ten ilustruje jednostka manifest w języku polskim, która z czasem, poprzez liczne przekłady z języka angielskiego, zyskała na rozszerzeniu jako manifest pokładowy 'dokument zawierający wykaz ładunku na statku lub w samolocie'.

Quasi-polisemia jest relacją pomiędzy wyrazami, które nieuchronnie w powtarzających się kontekstach zmieniają swoje znaczenie (Krzeszowski 2016: 107). Taki rodzaj polisemii nie jest zazwyczaj prezentowany w popularnych opracowaniach leksykograficznych. Jest on obrazowany przede wszystkim przez szereg alternacji, na przykład (za: Krzeszowski 2016: 107):

(1) typ-obiekt

ten telewizor (typ telewizora)

ten telewizor (mój telewizor)

(2) pojemnik-zawartość pojemnika

kufel (zbił się)

kufel (wypiłem dwa kufle)

Prawdziwa (absolutna) polisemia różni się od dwóch pozostałych tym, że nie poddaje się generalnym zasadom zmian znaczenia, a poszczególne warianty semantyczne mogą być rozpatrywane jedynie jako kontekstualnie stałe, indywidualne elementy w ramach danego leksemu (Krzeszowski 2016: 107). Można to rozumieć jako powiązania polisemiczne występujące jedynie w ramach fenomenu jednego, szeroko pojętego i wieloaspektowego (choć ograniczonego pewnymi ramami) pola semantycznego oraz kojarzonymi z nim relacjami metaforycznymi i metonimicznymi, jako centralna kategoria ze skonwencjonalizowanymi wariacjami. Przykładem może tu być wyraz głowa i związane z nim implikacje owych relacji. Ta jednostka leksykalna, a właściwie jej desygnat, zawiera receptory wszystkich zmysłów, jest zatem ośrodkiem wszelkich możliwych odczuć wyrażanych językowo. Istnieje wiele relacji zarówno metaforycznych, jak i metonimicznych, które w tłumaczeniu wykazują w tymże polu semantycznym zadziwiającą zbieżność w wielu językach.

\section{Polisemia międzyjęzykowa}

W przekładoznawstwie można również dokonać innych podziałów terminologicznych, np. na polisemię intralingwalną oraz na interlingwalną. Polisemia intralingwalna odnosi się do zjawiska wieloznaczności w ramach jednego języka, z kolei polisemia interlingwalna opisuje to zjawisko $w$ dwu lub większej liczbie języków jednocześnie (Gortych-Michalak 2013: 176). Z oczywistych względów to właśnie polisemia interlingwalna/międzyjęzykowa znajdzie się w centrum problematyki przekładoznawczej. W większości przypadków mamy do czynienia z polisemią intralingwalną, co w przekładzie skutkuje zazwyczaj zanikiem polisemiczności w języku docelowym. Angielski leksem armor/armour (pisownia amerykańska i brytyjska) oznacza 'zbroję', 
'opancerzenie' lub 'pancerz' (np. 'pancerz instalowany w czołgach, samochodach lub w szafach pancernych'). W tłumaczeniu na język polski, gdy z kontekstu wynika, iż chodzi o 'zbroję', ta polisemia znika. Co więcej, zbroja wcale nie musi składać się z płyt pancernych, możemy mieć np. do czynienia z wersją zbroi kolczej-kolczugi, w której jest 'osłona rycerza stworzona z koszuli wyplecionej metalowymi kulkami'. Z kolei polska nazwa kolczuga posiada kilka ekwiwalentów w języku angielskim, a mianowicie: mail, coat of mail, chain mail, ring mail, chain armor/armour, ring armor/armour. W tłumaczeniu zatem dość oczywiste wydaje się w takim wypadku zastosowanie odpowiedniego ekwiwalentu językowego.

Zdaniem autora niniejszej publikacji w wypadku polisemii interlingwalnej najbardziej pomocne są tak zwane uściślenia objaśniające. Często takich uściśleń wymaga np. jednostka kongres. O ile mieszkańcom Stanów Zjednoczonych leksem ten kojarzy się jednoznacznie $z$ amerykańskim parlamentem, to $w$ innych wypadkach sytuacja nie jest już taka oczywista. Ma to swoje odzwierciedlenie w tłumaczeniach. W wielu wypadkach można lub należy stosować uściślenia, szczególnie gdy z tekstu bezpośrednio nie wynika, o jaki kongres chodzi. Słowo to występuje w wielu nazwach parlamentów światowych, partii politycznych, stowarzyszeń religijnych, jednostkowych zjazdów oraz organizacji pozarządowych w wielu krajach, np. Kongres Stanów Zjednoczonych, Kongres Skonfederowanych Stanów Ameryki, Kongres Filipin, Kongres Hiszpański, Kongres eucharystyczny, Kongres Nowej Prawicy, Światowy Kongres Esperanto, Kongres Polonii Amerykańskiej, Kongres Wiedeński itp. Oczywiście, autor zdaje sobie sprawę faktu, że są to w przeważającej mierze nazwy własne, choć ludność autochtoniczna często nie używa całej nazwy, kierując się przeświadczeniem „wiadomo, o co chodzi". Nazwy Kongres Filipin oraz Kongres Hiszpański to typowe uściślenia, które informują odbiorcę, o jaką w przybliżeniu instytucję chodzi. W przybliżeniu, ponieważ dowiadujemy się o lokalizacji tych instytucji i podejrzewamy, że chodzi o krajowe ciała ustawodawcze. Tak jest w rzeczywistości - Kongres Filipin to nazwa własna dwuizbowego parlamentu w Manili, a Kongres Hiszpański to w istocie Kongres Deputowanych, czyli izba niższa parlamentu Królestwa Hiszpanii. Z kolei Kongres eucharystyczny nie jest nazwą własną i, o ile nie ma kontekstualnych wątpliwości co do tego, że ów kongres jest eucharystyczny, obowiązkiem tłumacza jest takie uściślenie zastosować.

\section{Konkluzje}

Polisemia i homonimia od zawsze stanowiły problemy translacyjne. Jeśli wieloznaczność często powoduje brak zrozumienia w ramach jednego języka, to w przekładzie te trudności mogą się jedynie potęgować. Tłumacz-profesjonalista winien posiadać odpowiedni warsztat teoretyczny, praktykę zawodową oraz - o czym rzadko się pisze, gdyż zapewne jest to truizm - talent. W związku z powyższym w przypadku trudności przekładowych związanych z polisemią i homonimią należy stosować następujące techniki: ekwiwalencje, uściślenia objaśniające oraz opisy objaśniające, przede 
wszystkim w formie przypisów, względnie w formie krótkich wyjaśnień w tekście podstawowym. Nie oznacza to oczywiście, że powinniśmy ograniczać się do tego typu narzędzi. Niekiedy pojawi się przecież konieczność zastosowań odpowiednich strategii, takich jak udomowienie i egzotyzacja, lub adekwatnych technik - transferu, transkrypcji, zapożyczeń, opuszczeń i in. Strategie te i narzędzia okażą się najbardziej użyteczne.

\section{Literatura}

Apresjan J., 1980, Semantyka leksykalna: synonimiczne środki języka, Wrocław: Ossolineum. Awramiuk E., 2011, Homonimia w funkcji impresywnej, „Białostockie Archiwum Językowe” nr 11.

Burkhanov I., 1998, Lexicography: a dictionary of basic terminology, Rzeszów: Wydawnictwo Wyższej Szkoły Pedagogicznej.

Buttler D., 1971a, Odmiany polskiej homonimii I: homonimy rdzenne, „Poradnik Językowy” z. 1.

Buttler D., 1971b, Odmiany polskiej homonimii Il: homonimy słowotwórcze, „Poradnik Językowy” z. 2.

Catford J.C., 1965, A linguistic theory of translation, London: Oxford University Press.

Chomsky N., 1965, Aspects of the theory of syntax, Massachusetts: The MIT Press.

Danilewicz T., 2011, Language awareness and second language teacher, Gdańsk: Wydawnictwo Uniwersytetu Gdańskiego.

Gizbert-Studnicki T., 1978, Wieloznacznośćleksykalna w interpretacji prawniczej, Kraków: Wydawnictwo Uniwersytetu Jagiellońskiego.

Gortych-Michalak K., 2013, Polisemia w przekładzie prawniczym grecko-polskim, "Comparative Linguistics", 13.

Hejwowski K., 2006, Kognitywno-komunikacyjna teoria przekładu, Warszawa: Wydawnictwo Naukowe PWN.

Hejwowski K., 2015, Iluzja przekładu, Katowice: Stowarzyszenie Inicjatyw Wydawniczych.

Kalisz M., 2016, Wybrane zagadnienia z zakresu problemów tłumaczeniowych terminologii języka komunizmu [w:] Doświadczenie komunizmu: pamięć i język, red. P. Zemszał, R. Halili, M. Głuszkowski, Toruń: Wydawnictwo Naukowe Uniwersytetu Mikołaja Kopernika.

Król M., 2014, Typologia homonimii językowej z punktu widzenia pragmatyki językowej, "Studia Rossica Posnaniensia", 39.

Krzeszowski T.P., 2016, The translation equivalence: meaning and translation, New York-London: Peter Lang.

Langacker R., 1987, Foundations o Cognitive Grammar: theoretical prerequisites, Stanford: Stanford University Press.

Lyons J., 1995, Linguistic semantic: an introduction, Cambridge: Cambridge University Press.

Majewska M., 2002, Homonimia i homonimy w opisie językoznawczym, Warszawa: Elipsa.

Nida E.A., 1964, Toward a science of translating: with special reference to principles and procedures involved in Bible translating, Leiden: E.J. Brill.

Sas A., Tabakowska E., 2014, Rozmowa z prof. Elżbietą Tabakowską z dn. 14.05.2014 [w:] Konferencja „Polisemia w języku i tłumaczeniu”, http://www.wszop.edu.pl/aktualnosci/konferencja-polisemia-w-jezyku-i-tlumaczeniu,1,1,2363 [dostęp: 6.05.2017]. 
Stanulewicz D., 2000, Nieprzetłumaczalność światów: indiańskie i europejskie opisy rzeczywistości [w:] Przekładając nieprzekładalne: Materiały z I Międzynarodowej Konferencji Translatorycznej, GdańskElbląg, t. 1, red. W. Kubiński, O. Kubińska, T.Z. Wolański, Gdańsk: Wydawnictwo Uniwersytetu Gdańskiego.

Venuti L., 1995, The translator's invisibility: a history of translation, London-New York: Routledge.

Wojan K., 2001, Fenomen homonimii międzyjęzykowej: rozważania językoznawcy, „Studia Scandinavica" 18.

Wojan K., 2004, Wstęp do analizy międzyjęzykowych homonimów leksykalnych na przykładzie języków: polskiego, rosyjskiego i fińskiego [w:] Język rosyjski w konfrontacji z językami Europy w aspekcie lingwokulturoznawczym, red. P. Czerwiński, H. Fontański, Katowice: Wydawnictwo Uniwersytetu Śląskiego.

Wojan K., 2007, Wspólnota homonimiki języków europejskich (na przykładzie języków: polskiego, rosyjskiego $i$ fińskiego), t. 1-3, niepublikowana rozprawa doktorska napisana pod kierunkiem prof. dr. hab. Jerzego Kaliszana, Poznań: Wydział Neofilologii, Uniwersytet im. Adama Mickiewicza w Poznaniu.

Wojan K., 2010, Wstęp do badań wieloznaczności leksemów w ujęciu kontrastywnym, Gdańsk: Wydawnictwo Uniwersytetu Gdańskiego.

Wojan K., 2013, Język angielski w polskiej leksykografii: słowniki przekładowe lingwistyczne i encyklopedyczne wydane w latach 1782-2012, Gdańsk: Wydawnictwo Uniwersytetu Gdańskiego.

Wojtasiewicz O., 1992, Wstęp do teorii tłumaczenia, wyd. 2, Warszawa: Tepis. 